\title{
DISMANTLING THE STATUS QUO: PROHIBITING UNFAIR DISCRIMINATION ON THE GROUNDS OF POVERTY UNDER CAPITALISM
}

\author{
by Sohela Surajpal*
}

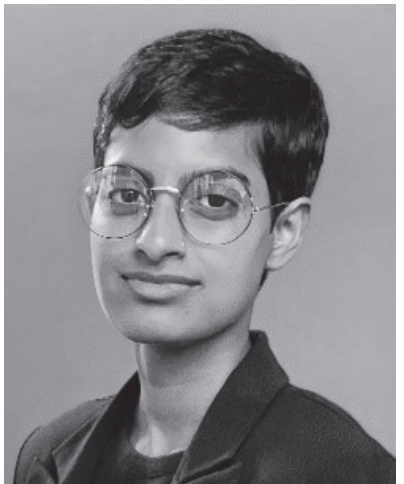

' 25 years into our democracy people, Black people in particular, still live under conditions which existed during the apartheid system of government. The dawn of democracy has not changed the lot of the people of Khayelitsha.'1

\section{Introduction}

In Social Justice Coalition $v$ Minister of Police, the Equality Court assessed the South African Police Services' (SAPS) presence in poor, predominantly black communities as compared to wealthier, white communities. Upon finding that SAPS allocated significantly fewer resources to impoverished communities, the court held that poverty is an analogous ground on which unfair discrimination may be based and that unfair discrimination had indeed taken place. ${ }^{2}$ While the author does not agree with increasing police presence in impoverished areas, this judgment has remarkable transformative potential. In the context of the transformative constitutionalism aims of the Constitution as a tool for transforming society from an unjust past to a more equal future, ${ }^{3}$ this paper questions how far the decision in

* LLB (Cum Laude), University of Pretoria. LLM Candidate at the University of Pretoria's Centre for Human Rights. ORCID: 0000-0002-2853-6558.

1 Social Justice Coalition and Others v Minister of Police and Others 2019 (4) SA 82 (WCC) para 90.

2 Social Justice Coalition v Minister of Police (n 1 above) para 65.

3 KE Klare 'Legal Culture and Transformative Constitutionalism' (1998) 14 (1) South African Journal on Human Rights 150. 
Social Justice Coalition could extend to prevent discrimination on the grounds of poverty in a capitalist society in which access to most goods, services and opportunities is contingent on wealth and in which the state has limited resources.

The first part of this paper discusses the approach of the South African courts to socio-economic rights, arguing that it has resulted in limited progress in alleviating poverty. The Equality Court's incorporation of equality law into socio-economic enquiries in Social Justice Coalition $v$ Minister of Police could strengthen the case of claimants and override certain factors that cause the courts to defer to the executive, thus compelling the State to provide more immediate relief. This section also attempts to apply the prohibition of discrimination on the grounds of poverty to commercial entities. By understanding discrimination as the denial of advantages or opportunities, the argument that the economy and private companies depend on discriminating against the poor to function is advanced.

The second part of the paper discusses the requirement that discrimination be unfair in order to be prohibited. It assesses the likelihood of courts finding that budgetary constraints and profit incentives are legitimate purposes served by discrimination on the grounds of poverty.

Finally, the last part of this paper discusses whether antidiscrimination law is an appropriate tool for the eradication of poverty. Several criticisms of transformative constitutionalism, human rights discourse and anti-discrimination law are engaged with to show that anti-discrimination law, as it currently exists, will at most target incidents of poverty-based discrimination using moderate forms of relief that allow for the continuance of an oppressive capitalist order rather than creating systemic change. The courts will have to make radical decisions, which depart from conservative South African legal culture if the decision in Social Justice Coalition $v$ Minister of Police is to have far reaching impact.

\section{How far could Social Justice Coalition $v$ Minister of Police extend?}

The Equality Court in Social Justice Coalition $v$ Minister of Police assessed SAPS presence in poor, black communities in the Western Cape. The SAPS allocated personnel and resources based on a multiple stage enquiry. First, it used socio-economic factors, crime statistics and other demographic factors to determine the theoretical number 
of personnel an area would require. ${ }^{4}$ Next, the SAPS considered its budgetary restraints to determine the allocation of resources that would be practically possible. Finally, resources were allocated to specific stations in terms of this weighting. ${ }^{5}$ While this system aimed to allocate more resources to disadvantaged areas, the factors it considered (such as available budget, population size, number of gangs present in the area and number of people who commute into the area) ultimately led to the SAPS allocating fewer resources to impoverished black communities. ${ }^{6}$ The Court applied the test for unfair discrimination in Harksen $v$ Lane and held that unfair discrimination had occurred on the grounds of race and poverty, the latter of which it considered to be an unlisted prohibited ground that 'adversely affects the equal enjoyment of a person's rights and freedom in a serious manner that is comparable to discrimination on a listed ground.'7

This section explores the potential of this judgment to facilitate the transformation of South African society in two ways. First, it asks whether the judgment could be used to challenge poverty more effectively through State policies. In doing so, the weaknesses of the current approach to poverty, which has prioritised socio-economic rights based litigation, is discussed and it is proposed that equality based litigation may bypass certain obstacles inherent to this approach. Secondly, this section asks whether the characterisation of poverty as a prohibited ground of discrimination could be applied to instances in which private businesses determine access to resources through differential treatment on the grounds of wealth and poverty.

\subsection{Vertical application: fighting poverty through State policies}

In a country that remains deeply divided on the grounds of race and class with vast levels of poverty bearing testament to the legacy of Apartheid and colonialism, the decision of the Equality Court appears to be a step towards a more just and equal society for all. ${ }^{8}$ Prior to this decision, courts and scholars have primarily used socio-economic rights as a mechanism for compelling the State to deliver services to impoverished communities. ${ }^{9}$ Socio-economic rights in South Africa

4 Social Justice Coalition v Minister of Police ( $\mathrm{n} 1$ above) para 22.

5 Social Justice Coalition $v$ Minister of Police ( 1 above) para 23.

6 Social Justice Coalition v Minister of Police (n 1 above) paras 41, 47.

7 Harksen $v$ Lane NO and Others 1998 (1) SA 300 in Social Justice Coalition $v$ Minister of Police (n 1 above) para 65.

8 BC Mubangizi and JC Mubangizi 'Poverty, human rights law and socio-economic realities in South Africa' (2005) 22 Development Southern Africa 278.

9 Mubangizi and Mubangizi (n 8 above) 277; S Sibanda 'Not purpose-made! transformative constitutionalism, post-independence constitutionalism and the struggle to eradicate poverty' (2011) 22 Stellenbosch Law Review 482; S Wilson \& J Dugard 'Taking poverty seriously: The South African Constitutional Court and socioeconomic rights' (2011) 22 Stellenbosch Law Review 672. 
include those related to labour law, an environment that is not harmful to one's health or wellbeing, property rights, the rights to access to housing, healthcare, food, water, education and social security. ${ }^{10}$ With efficient enforcement, these rights can ensure a significantly better quality of life for all South Africans.

While socio-economic rights are inarguably important and their application has resulted in several important victories for the impoverished, ${ }^{11}$ there are numerous obstacles that have prevented meaningful change through the application of socio-economic rights. In Soobramoney $v$ Minister of Health KwaZulu-Natal, ${ }^{12}$ Soobramoney made an application for an order compelling a public hospital to provide him with necessary medical treatment. The Court held that the hospital did not have the resources to provide him with this treatment especially given the numerous other patients who were also in need of treatment. This decision has been interpreted as support of the contention that socio-economic rights cannot be effectively enforced and protected by the courts since the allocation of resources should be determined by other branches of government and is dependent on the availability of resources. ${ }^{13}$ These institutional concerns have led to the courts adopting a strategy of judicial deference when adjudicating matters related to socioeconomic rights. Courts tend to defer to other branches of government that they characterise as more capable or legitimate, resulting in applicants being denied relief or being offered limited and inadequate relief. ${ }^{14}$ This approach has been criticised, with scholars such as Brand pointing out that while judicial overreach should be guarded against, the judiciary often mischaracterises other branches of government as uniquely vested with expertise and in doing so, weakens the impact of a transformative Bill of Rights specifically tailored to include justiciable socio-economic rights. ${ }^{15}$ Additionally, the obligations placed on the State with regards to socio-economic rights are negative and insofar as they are positive, only oblige the State to take reasonable measures to progressively realise such rights. ${ }^{16}$ Despite their potential, practical considerations have led to

10 Constitution of the Republic of South Africa, 1996 Chapter 2.

11 In cases such as Grootboom v Oostenberg Municipality 20003 BCLR 277 (C) and Minister of Health and Others $v$ Treatment Action Campaign and Others [2002] (5) SA 703 (CC) the courts held that the State failed to comply with its obligations in terms of socio-economic rights and compelled the State to take steps to provide access to rights such as housing and healthcare.

121998 (1) SA 765 (CC).

13 Mubangizi and Mubangizi (n 8 above) 283-284.

14 D Brand 'Judicial deference and democracy in socio-economic rights cases in South Africa' (2011) 3 Stellenbosch Law Review 618; EC Christiansen 'Adjudicating non-justiciable rights: Socio-economic rights and the South African Constitutional Court' (2007) 38 Columbia Human Rights Law Review 347-350.

15 Brand (n 14 above) 617-619.

16 Constitution secs $26(2)$ and $27(2)$. 
socio-economic rights yielding disappointing results and an alternative route is sorely needed.

The approach of the Equality Court in Social Justice Coalition v Minister of Police provides a possible alternative to socio-economic rights based litigation when attempting to address poverty. Rather than addressing SAPS policy through the lens of the right to safety and security, the Social Justice Coalition challenged the policy in terms of the Promotion of Equality and Prevention of Unfair Discrimination Act (PEPUDA). ${ }^{17}$ It is clear from a reading of the judgment that the reasoning of the Court may be applicable to other instances in which the State fails to allocate sufficient resources to poor communities or implements other policies that lead to unequal access to resources. Much like the allocation of SAPS resources, poor communities often have underfunded schools and hospitals or lack access to other basic needs such as water and electricity. ${ }^{18}$ According to PEPUDA, discrimination includes:

any act or omission, including a policy, law, rule, practice, condition or situation which directly or indirectly

(a) imposes burdens, obligations or disadvantages on; or

(b) withholds benefits, opportunities or advantages from any person on one or more of the prohibited grounds. ${ }^{19}$

Given the Court's characterisation of poverty as an unlisted ground, such a definition of discrimination could be extended to apply to instances in which poor people are denied benefits, opportunities and advantages such as access to quality education, healthcare, water and electricity among others.

While the State may not have many policies in place that purposefully dedicate more resources to wealthier communities, it is undeniable that wealthier areas have higher quality State institutions and infrastructure. An excellent example of this inequality can be found within the public education system. While much is said of the difference between private and public schools, inequality exists even within education provided by the State. Public schools in wealthy areas generally have better facilities since they were better funded under Apartheid and demand private contributions in the form of additional fees. ${ }^{20}$ Since such schools only accept students from the wealthy areas in which they are based and make use of other exclusionary policies - such as language policies and discriminatory admission processes - they are able to exclude poor students who

17 Act 4 of 2000.

18 Mubangizi \& Mubangizi (n 8 above) 481.

19 PEPUDÁ (n 17 above) sec 1.

20 See N Soekoe 'Untangling inequality in SA schooling' PoliticsWeb 20 November 2018 https://www.politicsweb.co.za/opinion/untangling-inequality-in-sa-schoo ling (accessed 22 November 2019). 
would ordinarily qualify for a fee exemption at a public school. ${ }^{21}$ This ultimately results in public schools in wealthy, predominately white areas offering education of a far higher quality than public schools in poor, predominately black areas. Policies such as limited geographical feeder zones for public schools may not have discriminatory intent but may still qualify as indirect forms of unfair discrimination on the ground of poverty, which, according to the Equality Court, should be challenged. ${ }^{22}$

De Vos argues that these enquiries into socio-economic rights can be strengthened by approaching them through the perspective of substantive equality. ${ }^{23}$ He stresses that the provision of socioeconomic rights by the State must be analysed in terms of substantive equality's focus on context and relative privilege. ${ }^{24}$ Such an approach would ensure that the State targets those communities that need aid most. Additionally, this strategy appears to have the benefit of avoiding the pitfall of judicial deference adopted by the courts when addressing socio-economic rights. The Respondents in Social Justice Coalition $v$ Minister of Police attempted to argue that in terms of the doctrine of separation of powers, the Court should refrain from judicial overreach and respect the expertise of the executive and administrative branches of government when allocating police resources. ${ }^{25}$ Rather than caving to this argument and deferring to other branches of government, the Court maintained that it was properly suited to decide on a matter regarding the right to equality, stating that:

The warning by the Constitutional Court to guard against judicial overreach and to defer to the administrative bodies with the necessary administrative expertise is a salutary one. It remains the duty of the Court, however, to protect the Constitutional rights and declare unlawful any act or omission, including a policy, law, rule, practice, condition or situation which directly or indirectly, imposes burdens, obligations or disadvantages on or withholds benefits opportunities or advantages from any person on one or more of the prohibited grounds. ${ }^{26}$

Since questions of unfair discrimination are viewed as within the scope of the judiciary's decision making power, this approach could help courts avoid falling into the trap of judicial deference to the executive when it is not appropriate. This approach can thus compel the State to address the needs of poor communities.

21 C Soudien \& $Y$ Sayed 'A new racial state? Exclusion and inclusion in education policy and practice in South Africa' (2004) 22 Perspectives in Education 109-111. Social Justice Coalition v Minister of Police ( 1 above) paras 36-37.

$23 \mathrm{P}$ de Vos 'Grootboom, the right of access to housing and substantive equality as contextual fairness' (2001) 172 South African Journal on Human Rights.

24 De Vos (n 23 above) 267.

25 Social Justice Coalition v Minister of Police (n 1 above) para 83.

26 Social Justice Coalition v Minister of Police (n 1 above) para 84. 


\subsection{Horizontal application: Could this decision be applied to private businesses?}

It appears clear that the Social Justice Coalition v Minister of Police decision could be used to compel the State to distribute its resources more equitably and rethink policies that indirectly discriminate against the poor, however, its application to private entities is more doubtful. De Waal and others claim that a distinction should be drawn between the vertical and horizontal application of certain rights. They argue that it would not be fair to impose the same burdens on private entities that we may rightly impose on the State. ${ }^{27}$ It is undoubtedly true that certain rights are enforceable to a different degree against private persons due to their nature, however, the prohibition of unfair discrimination applies to both the State and private persons as is made clear in Section 9(4) of the Constitution and Section 6 of PEPUDA. In discussing the importance of the prohibition of unfair discrimination by private businesses, De Vos uses the example of the parent of a disabled child who finds that cellular phone service providers, airlines, grocery stores, hotels and restaurants are unwilling to provide services to the child and parent on the grounds of a hypothetical religious belief. He stresses that without a prohibition on unfair discrimination by private companies, those groups of people who are targeted by prejudice may find themselves 'denied [their] basic rights to live a life in which [their] dignity is respected and protected' and would face disastrous consequences. ${ }^{28}$

Most people and South African courts would likely agree with this assessment. Given that private companies provide not just luxury goods, but many goods that are necessary for survival including food, clothing, transport and goods related to sanitation and hygiene. Denying a person access to the benefits offered by private businesses would likely leave them unable to survive. If this denial were based on a prohibited ground such as race or sexual orientation, it would constitute a disgusting example of unfair discrimination. The logical extension of this line of argumentation is that where a person is denied access to these benefits due to their poverty, or the results of their poverty - in other words, the inability to afford access to these goods - this constitutes unfair discrimination and is no less heinous than discrimination on any other prohibited ground. Take De Vos' reasoning discussed above and imagine that the parent of a disabled child was instead someone who lives in poverty, who finds that

27 J De Waal et al The Bill of Rights Handbook (1998) 33 - 34.

28 P de Vos 'Why private "businesses" cannot discriminate against gays and lesbians' Constitutionally Speaking 30 April 2013 https://constitutionallyspeaking.co.za/ why-private-businesses-cannot-discriminate-against-gays-and-lesbians/ (accessed 22 November 2019). 
cellular phone service providers, airlines, grocery stores, hotels and restaurants are unwilling to provide them with services. Surely, this should be viewed as equally discriminatory given the Equality Court's decision that poverty is a prohibited ground of discrimination.

Unfortunately, I remain doubtful that the courts would make a ruling to this effect any time in the near future, at least insofar as private businesses are concerned. To do so would destabilise the very foundations of capitalist society. The next section explores the likely justification courts would provide for not taking Social Justice Coalition $v$ Minister of Police to its logical, but radical conclusion.

\section{Possible obstacles to the application of Social Justice Coalition $v$ Minister of Police}

As was outlined in Harksen $v$ Lane, the test for unfair discrimination begins with an enquiry into whether differentiation has occurred on one of the prohibited grounds or an analogous ground. ${ }^{29}$ If the discrimination occurred on an analogous ground, unfairness must be proven by the complainant with reference to the impact of the discrimination on the complainant and others in their position. Following the reasoning of the Court in Social Justice Coalition $v$ Minister of Police, complainants will most likely succeed in meeting the requirements to prove that they have been denied benefits on the grounds of poverty, an unlisted and analogous ground and that this has had a severe impact on them and other impoverished people. The onus will then rest on the Respondent, be it the State or a private business, to show that their actions were in fact fair. This can be done by showing that the discrimination serves a legitimate purpose. ${ }^{30}$ Alternatively, the Respondent could prove that the challenged policy is a reasonable and justifiable limitation of the right to equality, in that the limitation serves an important purpose. ${ }^{3 \uparrow}$ Courts have held that affirmative action, measures necessary for the sustenance of the criminal justice system as well as the best interests of children serve legitimate purposes, therefore, rendering such discrimination fair or they constitute a reasonable and justifiable limitation of the right to equality. ${ }^{32}$ This section questions to what extent budgetary constraints, market forces and revenue would be considered legitimate purposes, thereby rendering discrimination on the grounds of poverty fair.

29 Harksen $v$ Lane (n 7 above) para 54.

30 PEPUDA (n 17 above) sec 14(3).

31 Constitution (n 10 above) sec 36.

32 President of the Republic of South Africa and Another v Hugo 1997 (4) SA 1 (CC); South African Police Service v Solidarity obo Barnard 2014 (6) SA 123 (CC). 


\subsection{Budgetary constraints for the State}

The South African State works with limited funds and resources to address poverty. Unlimited funds are not available to pump into public schools, housing and other infrastructure in poor communities. This unfortunate reality has been recognised numerous times by courts adjudicating socio-economic rights. ${ }^{33}$ In Grootboom, the Court stressed that an enquiry into the right to housing must be framed in terms of the reasonableness of the measures taken by the State, given its limited resources and the Constitution's allowance for the progressive realisation of socio-economic rights. ${ }^{34}$ Unless such practical limitations are considered by the courts, any order no matter how progressive or radical would have little impact if the State was unable to implement it. ${ }^{35}$ These budgetary constraints could, therefore, function as obstacles to equality-based litigation, in that they could qualify as a legitimate purpose served by the discrimination, in other words, preserving the State's budget and resources, therefore, allowing the State to continue functioning.

It is, however, important to note that the decision in Social Justice Coalition v Minister of Police does not necessarily compel the State to immediately solve the problems associated with poverty in order to give poor people the same quality of life as the wealthy. Instead, the Court determined that State policies that allocated more resources to wealthy communities or failed to allocate resources on a proportional, context-driven basis as informed by substantive equality were discriminatory. For example, rather than compelling the State to immediately upgrade all public schools in poorer communities, the State could be compelled to review exclusionary admissions policies or distribute funds from wealthier public schools more evenly. Additionally, the State could be compelled to address inefficiencies in the implementation of its policies or the misuse of resources, both of which often have a far greater negative impact on the success of State policies than a lack of funding. ${ }^{36}$ Such an approach does not focus on the circumstances of a poor community in isolation like socioeconomic rights based litigation does, but compares such circumstances to those in wealthy communities and asks how the State can be fairer and more equitable in terms of how it distributes its resources amongst those communities. This approach acknowledges that South Africa is not a country that lacks resources, but a country that has consistently failed to share its plentiful resources equitably. While taking cognisance of the practical 
limitations present, the Court in Social Justice Coalition $v$ Minister of Police stressed that:

The fact that there are socio-economic and infrastructural challenges which present difficulties to police efficiency and effectiveness in poor, Black areas cannot be a justification for inferior police services. ${ }^{37}$

This quote is a powerful statement, reflecting that while practical limitations must be considered and could in some instances render unequal service delivery fair discrimination, courts following the example of the Equality Court should not be too quick to reach this conclusion. Poor complainants challenging State policies through the lens of unfair discrimination therefore have decent prospects of success even in light of limited State resources.

\subsection{Market forces and revenue for private businesses}

Under capitalism, private businesses must secure a source of income in order to continue functioning. While some, like Google, have found ingenious ways of profiting without charging fees, the vast majority do so by charging customers a fee for the goods or services on offer. ${ }^{38}$ While much of this income lines the pockets of owners and CEOs, the income also covers necessary costs, including those of raw materials, manufacturing, transport, labour and other resources without which the company would fail. ${ }^{39}$ Given the necessity of income for private businesses, it is likely that despite the conclusion reached in the previous section, courts would rule that such discrimination is fair and that fees serve the legitimate purpose of allowing the business to continue functioning. One could argue that in most instances of discrimination by private businesses, an attempt to raise profit as a grounds of justifying discriminatory actions would fail. For example, a restaurant in a racist area that refuses to serve black customers because to do so would drive away white customers and therefore lead to a loss of profits, would find that their actions still constitute unfair discrimination. Unfortunately, the level of harm that would accrue to a private business that does not charge fees to the poor is likely to be far greater and would distinguish this circumstance from the former.

An optimist could claim that provided the State fulfils its burden of building a better, more equal society, with time poverty would be reasonably diminished and no such burden need be placed on private

37 Social Justice Coalition v Minister of Police (n 1 above) para 188.

38 M Visnji 'How Google makes money' Revenues and Profits 22 January 2019 https:/ /revenuesandprofits.com/how-google-makes-money/ (accessed 23 November 2019).

39 TC Wright 'Why are cost, revenue and profit important?' 22 July 2019 https:// yourbusiness.azcentral.com/cost-revenue-profit-important-21609.html (accessed 23 November 2019). 
businesses. In terms of a Marxist approach though, capitalism is dependent on the subjugation of the working class in order to function. ${ }^{40}$ The working class are kept impoverished so that they remain dependent on selling their labour to survive, thus driving industry, which thrives on the backs of an underpaid labour force. ${ }^{41}$ Poverty and class difference are therefore a necessary evil of capitalism, meaning that there will always be those who are unable to afford access to certain goods and services. This is especially disastrous given the above conclusion that private businesses cater to many needs and desires without which a person is incapable of living a decent and dignified life. ${ }^{42}$ This leaves us in a situation in which forcing private businesses to provide goods and services to the poor at no cost would doom these businesses to failure, while not doing so dooms millions of South Africans to a life in which their basic needs remain unmet.

\section{Social Justice Coalition v Minister of Police and transformative constitutionalism}

In order for the decision in Social Justice Coalition v Minister of Police to have an impact that extends to private businesses, the courts would have to take a radical anti-capitalist stance. This section criticises the Constitution and human rights discourse, illustrating that they ultimately uphold the unequal status quo. To give effect to this judgment, the courts would have to depart from conservative, deferential legal culture and truly take to heart the transformative vision of the Constitution as a tool for systemic change.

\subsection{Critique of the Constitution and rights based discourse}

Many decolonial scholars criticise the Constitution, framing it as a document of conquest and compromise. ${ }^{43}$ While there is no doubt that the Constitution and Bill of Rights have noble intentions, negotiations were significantly influenced by attempts to safeguard the interests of the white minority who wished to ensure that their interests would be protected once they no longer held political power in the democratic dispensation - a strategy that has allowed the white minority to maintain land, wealth and economic power. ${ }^{44}$

40 Engels \& Marx The communist manifesto (1969).

41 Engels and Marx (n 40 above).

42 De Vos (n 28 above).

43 T Madlingozi 'Social justice in a time of neo-apartheid constitutionalism: Critiquing the anti-black economy of recognition, incorporation and distribution; (2017) 28 Stellenbosch Law Review 142.

44 Madlingozi (n 43 above) 140. 
Given the unjust nature of wealth in South Africa, one of the key failings of the constitutional dispensation is its link to and acceptance of capitalism. The African National Congress, once a revolutionary liberation movement, quickly moved from a model of participatory democracy to neo-liberal capitalism once in power. ${ }^{45}$ Vogt points out that the economy was a major consideration both during debates on the Constitution and the Equality Bill:

During the debates on the Constitution, there was an indication that South Africa had ruled out equality of result since it had opted for a market economy. Indeed, the South African Law Commission and the African National Congress intended to include such an economic policy in the Bill of Rights, even though this is not the function of such a document. During the debates on the Equality Bill, the importance of the economy was stressed again. The choice of a market economy necessarily has an impact on the approach to racial equality. The economy, by its very nature, is driven by competition and thus cannot allow for an outcome where all would have the same standing. ${ }^{46}$

Kapur and Mutua further this analysis, showing that rights based discourse is inherently rooted in Western ideology that promotes individualism, liberalism and capitalism. ${ }^{47}$ They claim that rights based discourse will therefore never be successful in disrupting the systems from which it sprung, an argument that could be extended to the Constitution.

The Constitution and rights based discourse can, therefore, be viewed as mechanisms to preserve, rather than challenge the status quo. In a country that prioritises public interest litigation and human rights as an emancipatory scheme, marginalised groups hoping for change are forced to assimilate into the unjust system in order to receive benefits, rather than attempting to fundamentally change it. $^{48}$ The role that conservative, market focused legal culture has played in this is evident in Madlingozi's description of poor people's social movements, which are often forced to de-radicalise their aims in order to be more palatable to conservative courts. ${ }^{49}$ Rather than radically disrupting the status quo, the Constitution and Bill of Rights were created to maintain it, allowing at most for incremental change for a select black elite so long as it does not disturb the market

45 T Madlingozi 'Post-apartheid social movements and the quest for the elusive 'new' South Africa' (2007) 34 Journal of Law and Society 78-79.

46 GS Vogt 'Non-discrimination on the grounds of race in South Africa: With special reference to the Promotion of Equality and Prevention of Unfair Discrimination Act' (2001) 45 Journal of African Law 197-198.

47 M Mutua 'Savages, victims, and saviors: The metaphor of human rights' (2001) 42 Harvard International Law Journal 17; R Kapur 'In the aftermath of critique we are not in epistemic free fall: Human rights, the subaltern subject, and nonliberal search for freedom and happiness' (2014) 25 Springer Law Critique 25.

48 Madlingozi (n 43 above) 128.

49 T Madlingozi 'Social movements and the Constitutional Court of South Africa' in 0 Vilhena, U Baxi and F Viljoen (eds) Transformative constitutionalism: Comparing the apex courts of Brazil, India and South Africa (2013) 538. 
economy. ${ }^{50}$ This poses a clear obstacle to any attempt to apply the Social Justice Coalition $v$ Minister of Police decision widely, specifically with regard to private companies since such a decision would at most completely disrupt the capitalist free market and at least significantly damage the economy.

\subsection{A call for truly transformative 'transformative constitutionalism'}

It is possible that this conservative legal culture, in which courts defer to other branches of government when making policy decisions, is for the best. Judges, unlike the legislature and executive, are not democratically elected and so should not have the power to completely remake society with no democratic input. ${ }^{51}$ A shift from a capitalist to an alternative economic system closer to socialism or communism is a radical change that should be made through mass action or with input from all branches of government executing their democratic mandate, provided this shift is the will of the people.

It is difficult though to maintain this stance given that more than twenty years of democracy and constitutionalism have resulted in little economic change in the lives of everyday South Africans. ${ }^{52}$ Transformative constitutionalism calls on the legal fraternity to use the Constitution as a tool for large-scale social change. ${ }^{53}$ Klare envisaged this change taking the form of 'a transformation vast enough to be inadequately captured by the phrase 'reform,' but something short of or different from 'revolution' in any traditional sense of the word' 54 but it appears that South Africa has veered too close to reform rather than revolution. The decision of the Court in Social Justice Coalition $v$ Minister of Police makes it clear that the Constitution has the potential to steer the constitutional dispensation closer to its revolutionary roots, however, this will require the judiciary, legislature and executive to be brave enough to work together to disrupt the status quo. Perhaps this decision does not ask the courts to change the economic system of the country, but rather to stop prioritising capitalist interests over the values of freedom, equality and human dignity the Constitution mandates it to protect.

50 Madlingozi (n 43 above) 124-125.

51 Klare (n 3 above) 147-148.

52 JM Modiri 'Law's Poverty' (2015) 18 Potchefstroom Electronic Law Journal $224-225$.

53 Klare (n 3 above) 150.

54 As above. 


\section{Conclusion}

The judgment of Social Justice Coalition v Minister of Police is not a radical decision standing alone however it has the potential to inspire radical results should it be followed to its logical conclusions. Even a conservative reading of the judgment will lead to victories for the poor, in that they will be able to more effectively compel the State to combat poverty through the equitable allocation of its resources despite budgetary constraints. At its best, the judgment could find some degree of application in the interactions between poor people and private businesses who determine access to their goods and services on the grounds of wealth, although private businesses reliance on revenue for survival will be a significant obstacle. Such a reading will only be possible if courts shake off the conservative, deferential roles they have assumed in which they function to protect the market economy and unjust status quo and fully embrace transformative constitutionalism's vision of a Constitution that actively strives for a better life for all. 